Brit. F. vener. Dis. (1970) 46, 103

\title{
Male:female ratios in the V.D. clinics of England and Wales
}

\author{
R. S. MORTON \\ Royal Hospital, Sheffield
}

EvERY year the Chief Medical Officer for England and Wales publishes accumulated data regarding cases dealt with for the first time in some 200 V.D. clinics.

In his report for the year 1966 he drew attention to the fact that the male:female ratios in gonococcal infections showed a move in the direction of $1: 1$. These were his words: 'The fact that more cases in females are being brought under treatment may well be due to the increased efficiency of contact-tracing and this would be a matter for satisfaction'. In his report for the year following, that is for 1967, he stated 'The figures suggest that contact-tracing is being pursued diligently...'

\section{Aims and methods}

This short study reports on the limitations and usefulness of male:female ratios as indices of the efficiency of control of spread of gonorrhoea. Two lines of investigation are followed:

(a) Gonorrhoea ratios for the years 1961-68 inclusive are compared with other national male:female ratios in V.D. clinic populations.

(b) These ratios are compared with those found in an area serving some 1 per cent. of the total population and where speedy and tenacious contact-tracing has been a consistent policy throughout the study period.

\section{Findings}

(a) As Table I shows, the national male:female ratios in gonorrhoea have moved steadily over the study years in the direction of $1: 1$. The Table also shows the actual numbers of infections on which these ratios are founded. It will be seen that during the study years gonorrhoea in males increased by 10 per cent. The increase in females was of the order of 61 per cent. Improving ratios are therefore of limited value as control indicators.

TABLE I Male:female ratios in gonorrhoea, England and Wales, 1961-68

\begin{tabular}{|c|c|c|c|}
\hline \multirow{2}{*}{ Year } & \multicolumn{2}{|c|}{ No. of Infections } & Ratios \\
\hline & Male & Female & Male : Female \\
\hline $\begin{array}{l}1961 \\
1962 \\
1963 \\
1964 \\
1965 \\
1966 \\
1967 \\
1968\end{array}$ & $\begin{array}{l}29,519 \\
28,239 \\
27,895 \\
29,050 \\
27,886 \\
29,921 \\
30,645 \\
32,476\end{array}$ & $\begin{array}{r}7,588 \\
7,109 \\
8,154 \\
8,615 \\
8,805 \\
9,562 \\
11,184 \\
12,265\end{array}$ & $\begin{array}{l}3.89: 1 \\
3.98: 1 \\
3.44: 1 \\
3.38: 1 \\
3.16: 1 \\
2.92: 1 \\
2.74: 1 \\
2.65: 1^{\star}\end{array}$ \\
\hline Increase & 10 per cent. & 61 per cent. & \\
\hline
\end{tabular}

* Based on provisional figures.

This is emphasized further by a review of changing ratios in other spheres of clinic work where numbers, especially of female patients, are less subject to the influence of contact-tracing.

Table II shows the numbers of men and women requiring treatment for a condition other than syphilis, soft sore, gonorrhoea, or non-gonococcal urethritis; that is for conditions such as trichomoniasis, vaginal candidosis, genital herpes, genital

TABLE II Male:female ratios in three categories of V.D. clinic patients, England and Wales 1961-68

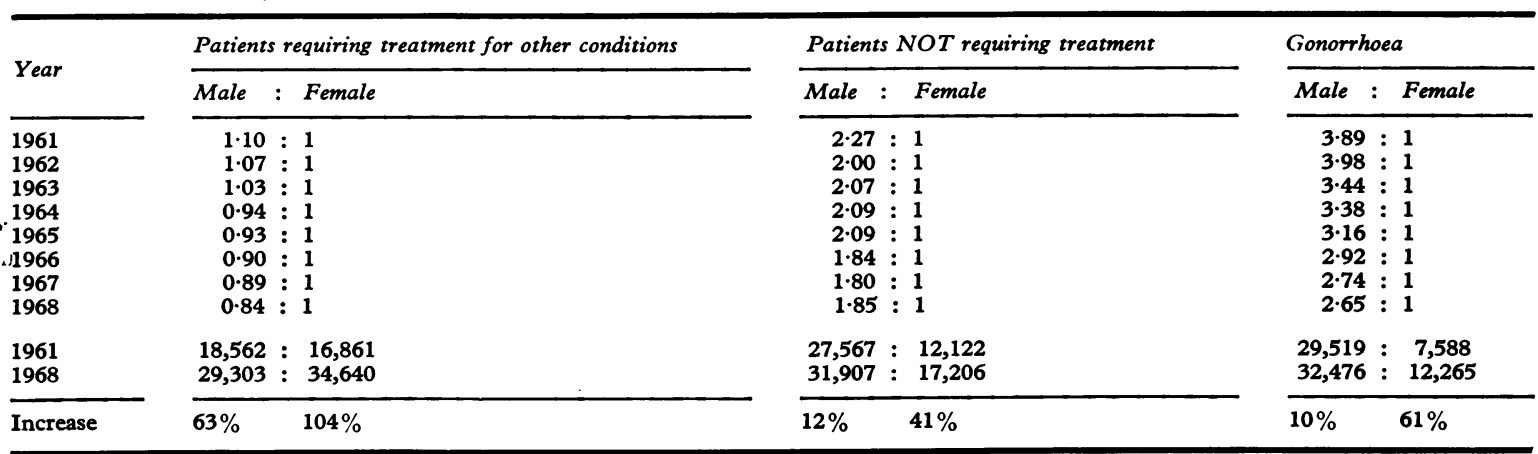


warts, scabies, pediculosis, etc. The ratio of males: females changed from $1 \cdot 1: 1$ in 1961 to $0.84: 1$ in 1968. In the cases of patients not requiring treatment, the ratio varied from $2 \cdot 27: 1$ in 1961 to $1 \cdot 85: 1$ in 1968 . Strict comparability with gonorrhoea ratios is not possible. What is apparent, however, is that growing demands on V.D. clinic services have been more marked in females than in males and it is this trend which has contributed most to all changing ratios. The ratio for patients requiring no treatment gives some clue as to how far this factor contributed to the change in gonorrhoea ratios.

(b) The second half of the study compares the national ratios with those of Sheffield, where the V.D. clinics serve a population of 500,000 , that is, about 1 per cent. of the total living in England and Wales.

Table III shows that the male:female ratio changes are in the same direction both nationally and locally for patients requiring treatment for other conditions and for those not requiring any treatment. As in the nation as a whole, these ratio changes are largely determined by a relatively greater demand on the service by females.

Compared with the average for other cities of half a million, the incidence of gonorrhoea in Sheffield is low. There are many reasons for this. Not least perhaps is the consistent pursuit of a policy of speedy and active contact-tracing throughout the study period. Not surprisingly, therefore, it is in gonorrhoea that the greatest difference between national and Sheffield ratios is found.

Table IV shows that the move in the male:female ratio towards $1: 1$ has been marginally faster in Sheffield year by year. The result has been that, while gonorrhoea in males has increased by 10 per cent. nationally, it has decreased by 2 per cent. locally. That this is in some measure due to more active contact-tracing is suggested by the comparison of increases in gonorrhoea in females. Whereas infections in females increased by 61 per cent. nationally, in
TABLE IV Male: Female ratios in gonorrhoea England and Wales compared with Sheffield, 1961-68

\begin{tabular}{|c|c|c|}
\hline \multirow{2}{*}{ Year } & England and Wales & Sheffield \\
\hline & Male : Female & Male : Female \\
\hline $\begin{array}{l}1961 \\
1962 \\
1963 \\
1964 \\
1965 \\
1966 \\
1967 \\
1968\end{array}$ & $\begin{array}{l}3.89: 1 \\
3.98: 1 \\
3.44: 1 \\
3.38: 1 \\
3.16: 1 \\
2.92: 1 \\
2 \cdot 74: 1 \\
2.65: 1\end{array}$ & $\begin{array}{l}3.31: 1 \\
3.7: 1 \\
2.34: 1 \\
2.14: 1 \\
1.69: 1 \\
2.22: 1 \\
1.66: 1 \\
1.72: 1\end{array}$ \\
\hline $\begin{array}{l}1961 \\
1968\end{array}$ & $\begin{array}{l}29,519: \quad 7,588 \\
32,476: 12,265\end{array}$ & $\begin{array}{l}348: 102 \\
325: 183\end{array}$ \\
\hline Increase & $10 \% \quad 61 \%$ & $79 \%$ \\
\hline
\end{tabular}

Sheffield the increase was 79 per cent. over the years studied.

\section{Summary and conclusions}

The study of male: female ratios of patients attending V.D. clinics and the comparison of national ratios with those in Sheffield indicate that there are many factors at work in determining male: female ratios in gonorrhoea. One important factor appears to be the relative preponderance of females in all diagnostic categories making increasing demands on clinic services.

As an index of control of gonorrhoea, the change in male: female ratios towards a 1:1 level is of limited value. However, if these ratios are qualified in terms of incidence of the disease in males, then they are a useful guide to the quality of contact-tracing and its contribution to control of dissemination of infection.

\section{References}

Ministry OF Health (1967), 'Report of the Chief Medical Officer for 1966', Part II 'On the State of the Public Health', p. 72. H.M.S.O., London (see Brit. F. vener. Dis. (1968), 44, 83).

(1968), Idem for 1967, p. 65 (see Brit. F. vener. Dis. (1969), 45, 67).

TABLE III Male:female ratios in two categories of V.D. clinic patients, England and Wales compared with Sheffield, 1961-68

\begin{tabular}{|c|c|c|c|c|c|}
\hline \multirow{2}{*}{ Year } & & \multicolumn{2}{|c|}{ Patients requiring treatment for other conditions } & \multicolumn{2}{|c|}{ Patients NOT requiring treatment } \\
\hline & & Male : Female & Male : Female & Male : Female & Male : Female \\
\hline $\begin{array}{l}1961 \\
1962 \\
1963 \\
1964 \\
1965 \\
1966 \\
1967 \\
1968\end{array}$ & $\cdots$ & $\begin{array}{l:l}1.10 & : 1 \\
1.07 & : 1 \\
1.03 & : 1 \\
0.94 & : 1 \\
0.93 & : 1 \\
0.90 & : 1 \\
0.89 & : 1 \\
0.84 & : 1\end{array}$ & 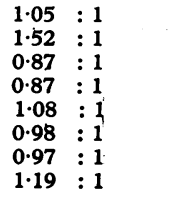 & 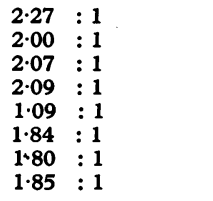 & 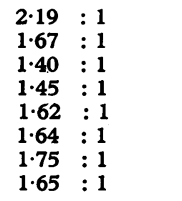 \\
\hline
\end{tabular}




\section{Le rapport cas masculins/cas féminins dans les cliniques vénéréologiques d'Angleterre et du Pays de Galles}

\section{SOMAIRE}

L'étude du rapport cas masculins/cas féminins chez les malades se présentant dans les cliniques vénéréologiques, et la comparaison de ces rapports pour tout le pays avec ceux de Sheffield, indique qu'il y a de nombreux facteurs agissant sur le rapport hommes/femmes dans la gonococcie.
Un des plus importants semble être la prépondérance relative des femmes venant consulter-pour toutes les catégories de diagnostic-dans ces cliniques.

Le mouvement du rapport hommes/femmes vers le taux de $1 / 1$ est d'une valeur limitée en tant qu'indice favorable dans la lutte contre la gonococcie. Cependant, si de tels rapports sont jugés en fonction de l'incidence de la maladie chez les hommes, ils deviennent alors un guide utile pour apprécier l'efficacité de la recherche des contacts et la contribution de celle-ci en tant que moyen de s'opposer à la dissémination de l'infection. 